\title{
KLASIFIKASI CACAHAN ECENG GONDOK UNTUK BAHAN KOMPOS YANG EFEKTIF TERHADAP TANAMAN HOLTIKULTURA
}

\author{
Mohamad Rizki Buheli'), Yunita Djamalu²), Siradjuddin Haluti ${ }^{3)}$ \\ ${ }^{1}$ Mahasiswa Program Studi Mesin dan Peralatan Pertanian, Politeknik Gorontalo \\ ${ }^{2,3}$ Dosen Program Studi Mesin dan Peralatan Pertanian, Politeknik Gorontalo \\ e-mail: rizkibuheli123@gmail.com,naura@poligon.ac.id
}

\begin{abstract}
ABSTRAK
Eceng gondok adalah tanaman yang tumbuh disekitar danau, tanaman ini disebut sebagai tanaman pengganggu oleh masyarakat sekitar danau karena merusak lingkungan perairan. Dari sisi ekonomi penggunaan pupuk kompos cair lebih murah dan efektif dibandingkan dengan pupuk organik cair hasil pabrikan. Disamping bahan baku yang cukup meluas juga dapat diprduksi dengan skala yang lebih besar sehingga dapat meminimalisir biaya pemupukan yang berdampak efesiensi untuk anggaran petani.Tujuan penelitian ini adalah menentukan klasifikasi cacahan eceng gondok untuk pupuk kompos cair, menentukan campuran pengomposan untuk pupuk kompos cair, dan mengetahui dampak pemberian pupuk kompos cair terhadap tanaman holtikultura.Dari hasil studi kasus klasifikasi cacahan eceng gondok untuk bahan kompos yang efektif terhadap tanaman holtikultura dapat diambil kesimpulan bahwa pupuk kompos cair dari eceng gondok berdampak positif bagi tanaman holtikultura, walaupun ada tanaman yang tidak mengalami pertumbuhan jumlah daun karena kurangnya kandungan $\mathrm{N}$ pada pupuk kompos itu sendiri.
\end{abstract}

Kata Kunci: Klasifikasi ,cacahan, eceng gondok, bahan kompos, tanaman holtikultura.

\section{ABSTRACT}

Water hyacinth is a plant that grows around the lake, this plant is referred to as a nuisance plant by the community around the lake because it damages the aquatic environment. From an economic standpoint, the use of liquid compost fertilizer is cheaper and more effective compared to liquid organic fertilizer produced by the manufacturer. Besides the raw material which is quite extensive, it can also be produced on a larger scale so as to minimize the cost of fertilization which has an efficient impact on the farmer's budget. the impact of liquid compost fertilizer on horticulture plants. From the case study results of the classification of water hyacinth counts for effective compost material on horticulture plants, it can be concluded that liquid compost fertilizer from water hyacinth has a positive impact on horticulture plants, although there are plants that do not experience growth in the number of leaves due to lack of $N$ content in compost itself.

Keywords: Classification, counting, water hyacinth, compost material, horticultural crops. 


\section{PENDAHULUAN}

\section{Latar Belakang}

Eceng gondok (Eichornia crassipes) merupakan tumbuhan air mengapung karena memiliki daun yang tebal dan gelembung (Rorong \& Suryanto 2010) yang berkembang biak sangat cepat sehingga dianggap sebagai tanaman yang dapat merusak lingkungan perairan (Gerbono \& Djarijah 2005; Stefhani et al. 2013).

Mesin pencacah eceng gondok telah banyak digunakan dalam pembuatan pupuk, mesin pencacah eceng gondok sebelumnya sebagai penghacur bahan organik seperti didaunan, rumput-rumputan dan sisasisa hasil pertanian dengan cara mencacahnya sampai dengan ukuran kecil-kecil berkisar 1-5 mm, sisa sisa hasil pertanian tidak pernah dimanfaatkan dengan baik sehingga hanya menjadi limbah tanpa adanya nilai guna tambahan.

\section{Pupuk Kompos}

Dari sisi ekonomi penggunaan pupuk kompos cair lebih murah dan efektif dibandingkan dengan pupuk organik cair hasil pabrikan. Disamping bahan baku yang cukup meluas juga dapat diproduksi dengan skala yang lebih besar sehingga dapat meminimalisir biaya pemupukan yang berdampak efesiensi untuk anggaran petani.

Beberapa penelitian telah dilakukan yang berhubungan dengan pupuk kompos cair. "Pupuk Organik Eceng Gondok Dari Danau Toba" (Rita Juliani.,dkk 2017). Tujuan dari PKM - M membantu masyarakat untuk mengolah eceng gondok yang ada di Danau Toba menjadi pupuk organik yang berguna bagi masyarakat. Metode yang digunakan dalam pelatihan meliputi sosialisasi, pelatihan serta monitoring dan evaluasi. Bahan yang digunakan untuk pembuatan pupuk organik adalah enceng gondok, EM4 dan plastik hitam. Alat yang dirancang adalah penggiling eceng gondok, bak fermentasi eceng gondok. Kegiatan Training dilaksanakan di Desa Naburahan Limbong. Metode yang dilakukan meliputi 4 tahap, yaitu tahap sosialisasi, tahap pelatihan, tahap monitoring dan evaluasi.

Kompos mengalami tiga tahap proses pengomposan yaitu Padatahap pertama yaitu tahap penghangatan (tahap mesofilik), mikroorganisme hadir dalam bahan kompos secara cepat dan temperatur meningkat. Mikroorganisme mesofilik hidup pada temperatur $10-45 \mathrm{oC}$ dan bertugas memperkecil ukuran partikel bahan organik sehingga luas permukaan bahan bertambah dan mempercepat proses pengomposan. Pada tahap kedua yaitu tahap termofilik, mikroorganisme termofilik hadir dalam tumpukan bahan kompos.Mikroorganisme termofilik hidup pada tempratur $45-60 \mathrm{oC}$ dan bertugas mengkonsumsi karbohidrat dan protein sehingga bahan kompos dapat terdegradasi dengan cepat.Mikroorganisme ini berupa Actinomycetes dan jamur termofilik.Sebagian dari Actinomycetes mampu merombak selulosa dan hemiselulosa. Kemudian proses dekomposisi mulai melambat dan temperatur puncak dicapai. Setelah temperatur puncak terlewati, tumpukan mencapai kestabilan, dimana bahan lebih mudah terdekomposisikan.

Tahap ketiga yaitu tahap pendinginan dan pematangan.Pada tahap ini, jumlah mikroorganisme termofilik berkurang karena bahan makanan bagi mikroorganisme ini juga berkurang, hal ini mengakibatkan organisme mesofilik mulai beraktivitas kembali. Organisme mesofilik tersebut akanmerombak selulosa dan hemiselulosa yang tersisa dari proses sebelumnya menjadi gula yang lebih sederhana, tetapi kemampuanya tidak sebaik organism termofilik. Bahan yang telah didekomposisi menurun jumlahnya dan panas yang dilepaskan relatif kecil (Djuarnani dkk.,2005).

\section{METODOLOGI PENELITIAN}

\section{Jenis dan Pendekatan}

Penelitian Jenis dan pendekatan penelitian pada tugas akhir ini menggunakan metode penelitian kajian kepustakaan. Yang dimaksud penelitian kepustakaan adalah penelitian yang dilakukan hanya berdasarkan atas karya tertulis, termasuk hasil penelitian baik yang telah maupun yang belum dipublikasikan (Embun, 2012).

Penelitian dengan studi literatur tidak harus turun ke lapangan dan bertemu dengan responden. Data-data yang dibutuhkan dalam penelitian dapat diperoleh dari sumber pustaka atau dokumen. Menurut (Zed, 2014), pada riset pustaka (library research), penelusuran pustaka tidak hanya untuk langkah awal menyiapkan kerangka penelitian (research design) akan tetapi sekaligus memanfaatkan sumber-sumber perpustakaan untuk memperoleh data penelitian.

\section{Sumber Data}

Sumber data penelitian tugas akhir ini diperoleh dari karya ilmiah berupa jurnal-jurnal elektronik (ejurnal) atau dokumen-dokumen atau karya ilmiah berupa tulisan tugas akhir terdahulu yang banyak ditemukan di internet. 


\section{Pengumpulan Data}

Untuk memperoleh data yang diinginkan, terlebih dahulu dilakukan pengumpulan / inventarisasi kata kunci / keyword yang berkaitan dengan jenis bahan bakar alternatif, serta kriteria kriteria pengujian suatu jenis bahan bakar untuk kemudian dimasukkan ke dalam kolom dari salah satu mesin pencarian di media internet, dalam hal ini google search engine (mesin pencari google) di situs www.google.com.

\section{Analisis Data}

Data-data yang diperoleh dari jurnal - jurnal elektronik, selanjutnya diolah. Pengolahan data bertujuan untuk mempermudah dalam melakukan analisis data. Teknik analisa data yang digunakan ada 2 macam, yaitu analisa deskriptif dan analisa inferensial. Analisa Deskriptif adalah analisa yang berhubungan dengan metode pengelompokan dan peringkasan data sehingga penyajian data akan lebih informatif. Analisa inferensial dilakukan untuk mencari hubungan antara variable satu dengan yang lain kemudian menentukan sebuah kesimpulan terhadap variabel tersebut. Kedua metode analisis ini tersaji dalam tabel-tabel pada bab pembahasan.

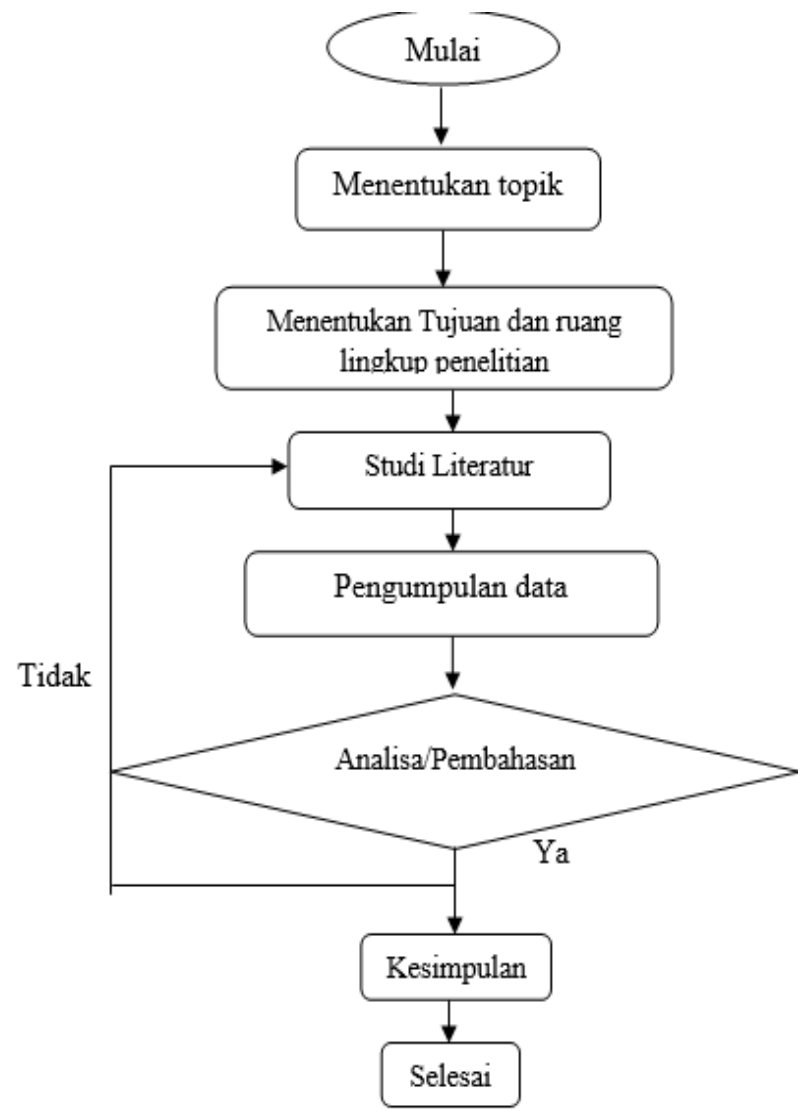

\section{HASIL DAN PEMBAHASAN}

\section{Klasifikasi Cacahan Eceng Gondok}

Berdasarkan kajian pustaka yang dilakukan pada studi kasus ini adalah mendalami klasifikasi cacahan yang bagus digunakan untuk pembuatan pupuk kompos cair,dapat kita ambil perbandingan klasifikasi cacahan seperti pada tabel 1 .

Tabel 1 kriteria cacahan sesuai dengan kajian pustaka.

\begin{tabular}{lll}
\hline No & \multicolumn{1}{c}{ Nama } & Kriteria Cacahan \\
\hline 1 & Rita Juliani., dkk 2017 & Seperti Bubur \\
\hline 2 & Anastasia R. Moia.,dkk 2015 & Kasar \\
\hline 3 & Yanuarisma 2017 & Halus \\
\hline 4 & Dhanisa Fitri Monanda 2019 & $1-2 \mathrm{~cm}$ \\
\hline 5 & Euthalia Hanggari Sittadewi 2007 & $2 \mathrm{~cm}$ \\
\hline
\end{tabular}

Dari tabel diatas penelitian (Rita Juliani., dkk 2017) untuk tanaman cabe kriteria cacahannya seperti bubur karena dilakukan pencacahan terlebih dahulu dengan menggunakan mesin pencacah agar mempermudah proses pencampuran dan lebih cepat proses fermentasinya sehingga pupuk dapat digunakan dalam beberapa hari saja atau kurang dari seminggu.( Anastasia R. Moia.,dkk 2015) untuk tanaman sawi dirajang atau dipotong-potong secara manual dengan menggunakan benda tajam seperti parang sehingga hasil cacahannya tidak halus melainkan kasar berkisar 2-3 cm. Untuk( Yanuarisma 2017) digiling tetapi kriteria cacahan hanya halus tidak seperti (Rita Juliani., dkk 2017) yang menjadi bubur.( Dhanisa Fitri Monanda 2019) dipotong-potong secara manual dengan ukuran 1-2 cm seperi kriteria cacahan (Euthalia Hanggari Sittadewi 2007) tetapi menggunakan mesin pencacah.

\section{Campuran Pengomposan}

Campuran pengomposan juga pelu diketahui dalam pembuatan pupuk kompos karena dapat mengubah bahan organik yang biodegradable menjadi bahan yang stabil, membunuh mikroba pathogen, telur serangga, organisme lain dan menyediakan nutrisi yang cukup untuk menunjang kesuburan tanah / tanaman . pencampuran dapat dilihat pada tabel 2.

Gambar 1. Diagram alir penelitian 
Tabel 2 menentukan campuran pengomposan untuk pupuk kompos cair

\begin{tabular}{lll}
\hline No & \multicolumn{1}{c}{ Nama } & Campuran \\
\hline 1 & $\begin{array}{l}\text { Rita Juliani., dkk } \\
2017\end{array}$ & 1 ml EM4 \\
\hline 2 & $\begin{array}{l}\text { Anastasia R. } \\
\text { Moia.,dkk 2015 }\end{array}$ & $5-10 \mathrm{ml}$ EM4 \\
\hline 3 & Yanuarisma & Dedak 0,625 kg, sekam \\
& 2017 & $3,75 \mathrm{~kg}$, dan stardex \\
\hline 4 & Dhanisa Fitri & Larutan gula merah 50 ml \\
& Monanda 2019 & dan Larutan EM4 5 ml \\
\hline 5 & Euthalia & Kotran ayam kelembapan \\
& Hanggari & 60\%, EM4, Gambut rawa \\
& Sittadewi 2007 & kelembapan 60\%. \\
\hline
\end{tabular}

Dari tabel 2 dapat kita lihat perbandingan campuran pengomposan pada setiap pembuatan pupuk, dari keenam penelitian diatas semuanny hampir menggunakan campuran EM4 tetapi tidak dengan (Yanuarisma 2017), dia menggantinya dengan menggunakan campuran stardex yaitu slah satu campuran bio aktivator pengomposan yang banyak digunakan pada industri kompos. Dapat kita lihat campuran sabut kelapa, batang pisang, $800 \mathrm{~g}$ gula, Dedak 0,625 kg, sekam 3,75 kg, stardex, Larutan gula merah $50 \mathrm{ml}$, Kotran ayam kelembapan $60 \%$, Gambut rawa kelembapan 60\%. Semua campuran diatas tidak lain untu lebih meningktkan proses perumbuhan dan kesuburan baik pada tanah dan juga tanaman itu sendiri walau setiap tanaman memiliki reaksi yang berbeda beda

\section{Klasifikasi kesuburan tanaman akibat penggunaan pupuk kompos cair.}

Kriteria cacahan, dan campuran penngomposan kita dapat melihat dampak kesuburan apakah baik atau tidaknya penggunaan pupuk kompos cair pada tanaman seperti tabel 3 .

Kesimpulan dari kelima hasil yang didapat adalah klasifikasi cacahan jika lebih halus akan lebih bagus pada saat pencampuran dan juga penamban bahan lain seperti EM4, kotoran ayam akan lebih bagus tetapi penambahan harus disesuaikan dengan kebutuhan tanaman karena ketika kelebihan nitrigen akan tidak bagus juga buat tanaman itu sendiri, sebab juka kandungan nitrogen seimbang akan memberikan dampak yang baik bagi tanaman, kecukupan unsur hara $\mathrm{C}, \mathrm{P}$ dan $\mathrm{K}$ sangat diperlukan karena jika kekurangan hara $\mathrm{K}$ akan mengakibatkan tanaman tidak tahan terhadap penyakit dan juga tidak tahan terhadap kekeringan (Rismunandar,1990). Kelima hasil tersebut disajikan dalam tabel klasifikasi kesuburan tanaman.
Tabel 3 Klasifikasi kesuburan tanaman.

\begin{tabular}{|c|c|c|c|c|c|}
\hline \multirow{2}{*}{\multicolumn{2}{|c|}{ No Nama }} & \multirow{3}{*}{$\begin{array}{l}\text { Kriteria } \\
\text { Cacahan }\end{array}$} & \multirow{2}{*}{\multicolumn{2}{|c|}{ Campuran Jenis }} & \multirow{3}{*}{$\begin{array}{l}\text { Dampak } \\
\text { kesuburan } \\
\text { bagi } \\
\text { tanaman }\end{array}$} \\
\hline & & & & & \\
\hline & & & & & \\
\hline 1 & $\begin{array}{l}\text { Rita } \\
\text { Juliani., } \\
\text { dkk } 2017\end{array}$ & $\begin{array}{l}\text { Seperti } \\
\text { Bubur }\end{array}$ & 1 ml EM4 & Cabe & $\begin{array}{l}\text { Pertumbuh } \\
\text { an daun } \\
\text { bertambah. }\end{array}$ \\
\hline 2 & $\begin{array}{l}\text { Anastasia } \\
\text { R. } \\
\text { Moia.,dkl } \\
2015\end{array}$ & Kasar & $\begin{array}{l}5-10 \mathrm{ml} \\
\text { EM4 }\end{array}$ & Sawi & $\begin{array}{l}\text { Tinggi } \\
\text { tanaman } \\
\text { sawi } \\
\text { bertambah. }\end{array}$ \\
\hline 3 & $\begin{array}{l}\text { Yanuaris } \\
\text { ma } 2017\end{array}$ & Halus & $\begin{array}{l}\text { Dedak } \\
0,625 \mathrm{~kg}, \\
\text { sekam } 3,75 \\
\mathrm{~kg} \text {, dan } \\
\text { stardex }\end{array}$ & Selada & $\begin{array}{l}\text { Tinggi } \\
\text { tanaman, } \\
\text { berat akar } \\
\text { tanaman, } \\
\text { berat } \\
\text { selada, } \\
\text { tetapi tidak } \\
\text { berpengaru } \\
\text { h terhadap } \\
\text { jumlah } \\
\text { daun. }\end{array}$ \\
\hline 4 & $\begin{array}{l}\text { Dhanisa } \\
\text { Fitri } \\
\text { Monanda } \\
2019\end{array}$ & $1-2 \mathrm{~cm}$ & $\begin{array}{l}\text { Larutan } \\
\text { gula merah } \\
50 \mathrm{ml} \mathrm{dan} \\
\text { Larutan } \\
\text { EM4 } 5 \mathrm{ml}\end{array}$ & Selada & $\begin{array}{l}\text { Pertumbuh } \\
\text { an baik } \\
\text { untuk } \\
\text { selada }\end{array}$ \\
\hline 5 & $\begin{array}{l}\text { Euthalia } \\
\text { Hanggari } \\
\text { Sittadewi } \\
2007\end{array}$ & $2 \mathrm{~cm}$ & $\begin{array}{l}\text { Kotran } \\
\text { ayam } \\
\text { kelembapa } \\
\text { n } 60 \% \text {, } \\
\text { EM4, } \\
\text { Gambut } \\
\text { rawa } \\
\text { kelembapa } \\
\text { n } 60 \% \text {. }\end{array}$ & $\begin{array}{l}\text { Sawi } \\
\text { Hibrida }\end{array}$ & $\begin{array}{l}\text { Memberika } \\
\mathrm{n} \text { respons } \\
\text { positif } \\
\text { bahawa } \\
\text { tanaman } \\
\text { tumbuh } \\
\text { segar dan } \\
\text { sehat tanpa } \\
\text { ada } \\
\text { gangguan } \\
\text { penyakit. }\end{array}$ \\
\hline
\end{tabular}

Dari hasil Anastasia R. Moia.,dkk 2015 dan Euthalia Hanggari Sittadewi 2007 untuk tanaman sawi non hibrida dan sawi hibrida yaitu Tinggi tanaman sawi bertambah juga Memberikan respons positif bahawa tanaman tumbuh segar dan sehat (tanpa ada gangguan penyakit). Hal ini dikarenakan bahwa pupuk kompos baik buat kedua tanaman dan perbandingannya juga dapat dilihat pada pencampuran dan jenis tanaman itu sendiri seperti sawi hibrida lebih unggul daripada sawi non hibrida karena produksinya tinggi, pertumbuhan tanaman cepat, ketika ditambahkan pupuk kompos tanaman memberikan dampak yang positif. Adapun hasil Yanuarisma 2017 dan Dhanisa Fitri Monanda 2019 untuk tanaman selada perbandingan dapat dilihat pada jumlah daun yang tidak berpengaruh setelah pemberian pupuk. Dan yang terakhir hasil Rita 
Juliani., dkk 2017 untuk tanaman cabe pertumbuhan daun bertambah walaupun pada pencampuran hanya menggunakan laruran EM4 hal ini disebabakan karena tanaman cabe tidak banyak perawatan yang harus dilakukan, jadi ketika penambahan pupuk pada cabe sangat membantu pertumbuhan daun, namun ketika diberikan tambahan campuran seperti kotoran ayam ada kemungkinan dampak pada tanaman jauh lebih dari pertumbuhan daun saja.

\section{Kesimpulan}

- Dari hasil studi kasus klasifikasi cacahan eceng gondok untuk bahan kompos yang efektif terhadap tanaman holtikultura dapat diambil kesimpulan bahwa pupuk kompos cair dari eceng gondok adalah sebagai berikut :Cacahan eceng gondok yang baik untuk digunakan sebagai dasar pembuatan pupuk kompos adalah penelitian Rita Campuran pupuk kompos yang baik yaitu cukup menambahkan $1 \mathrm{ml}$ EM4 pada pencampuran kompos itu sudah membantu dalam pertumbuhan tanamaman seperti penelitian Rita juliani.,dkk 2017 untuk tanaman cabe.

- Dampak terhadap kesuburan tanaman memberikan respon positif walau ada yang tidak mengalami. juliani.,dkk 2017 walaupun semua hasil cacahan dapat digunakan sebagai dasar tetapi, jika hasil cacahannya lebih halus dari ukuran umum 1-5 mm akan mempermudah proses pencampuran dan juga mempercepat proes fermentasinya.

\section{REFERENSI}

Gerbono A, Djarijah AS. 2005. Kerajinan Eceng Gondok. Yogyakarta (ID): Kanisius.

Rita Juliani.,dkk 2017 Pupuk Organik Enceng Gondok Dari Danau Toba Jurusan Fisika,Fakultas Matematika dan Ilmu Pengetahuan Alam, Universitas Negeri Medan

Embun, B. (2012, April 17). Banjir Embun. Retrieved from Penelitian Kepustakaan:

Zed, M. (2014). Metode Penelitian Kepustakaan. Jakarta: Yayasan Obor Indonesia

Anastasia R.Moia.,dkk 2015 Pengujian Pupuk Organik Cair dari Eceng Gondok (Eichhornia crassipes) Terhadap Pertumbuhan Tanaman Sawi (Brassica juncea) Jurusan Biologi, FMIPA, Unsrat, Manado

Yanuarisma, 2012, Pengaruh Kompos Enceng Gondok (Eichornia Crassipes Solm) Terhadap Pertumbuhan Dan Produksi Selada (Lactuca
Sativa L) Fakultas Keguruan Dan Ilmu Pendidikan Universitas Muhammadiyah Surakarta

Dhanisa Fitri Monanda,2019. Pengaruh Pemberian Pupuk Organik Cair Eceng Gondok (Eichornia Crassipes)(Mart)Solms. Terhadap Pertumbuhan Tanaman Selada (Lactuca Sativa L.) Jurusan Biologi Fakultas Matematika Dan Ilmu Pengetahuan Alam Universitas Lampung

Euthalia Hanggari Sittadewi 2007 Engolahan Bahan Organik Eceng Gondok Menjadi Media Tumbuh Untuk Mendukung Pertanian Organik Peneliti Pada Pusat Teknologi Lahan Wilayah Dan Mitigasi Bencana Badan Pengkajian Dan Penerapan Teknologi. Jakarta 